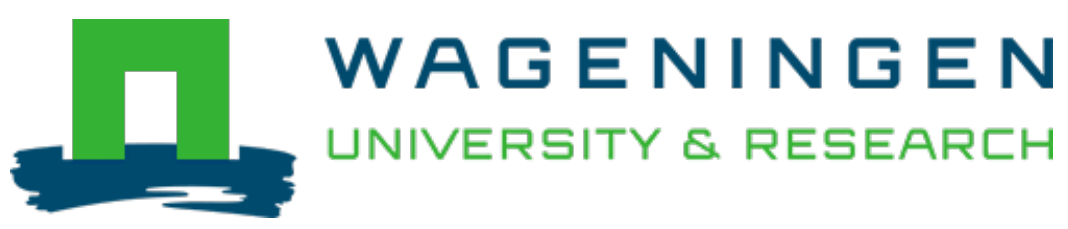

\title{
The politics of securitization : China's competing security agendas and their impacts on securitizing shared rivers
}

\author{
Eurasian Geography and Economics \\ Xie, Lei; Warner, Jeroen \\ https://doi.org/10.1080/15387216.2020.1870516
}

This publication is made publicly available in the institutional repository of Wageningen University and Research, under the terms of article $25 \mathrm{fa}$ of the Dutch Copyright Act, also known as the Amendment Taverne. This has been done with explicit consent by the author.

Article 25 fa states that the author of a short scientific work funded either wholly or partially by Dutch public funds is entitled to make that work publicly available for no consideration following a reasonable period of time after the work was first published, provided that clear reference is made to the source of the first publication of the work.

This publication is distributed under The Association of Universities in the Netherlands (VSNU) 'Article $25 \mathrm{fa}$ implementation' project. In this project research outputs of researchers employed by Dutch Universities that comply with the legal requirements of Article $25 \mathrm{fa}$ of the Dutch Copyright Act are distributed online and free of cost or other barriers in institutional repositories. Research outputs are distributed six months after their first online publication in the original published version and with proper attribution to the source of the original publication.

You are permitted to download and use the publication for personal purposes. All rights remain with the author(s) and / or copyright owner(s) of this work. Any use of the publication or parts of it other than authorised under article $25 \mathrm{fa}$ of the Dutch Copyright act is prohibited. Wageningen University \& Research and the author(s) of this publication shall not be held responsible or liable for any damages resulting from your (re)use of this publication.

For questions regarding the public availability of this publication please contact openscience.library@wur.nl 


\section{Eurasian Geography and Economics}

\section{The politics of securitization: China's competing security agendas and their impacts on securitizing shared rivers}

\section{Lei Xie \& Jeroen Warner}

To cite this article: Lei Xie \& Jeroen Warner (2021): The politics of securitization: China's competing security agendas and their impacts on securitizing shared rivers, Eurasian Geography and Economics, DOI: 10.1080/15387216.2020.1870516

To link to this article: https://doi.org/10.1080/15387216.2020.1870516

曲 Published online: 04 Jan 2021.

Submit your article to this journal $\widetilde{ }$

山 Article views: 41

Q View related articles ¿

View Crossmark data $־$ 


\title{
The politics of securitization: China's competing security agendas and their impacts on securitizing shared rivers
}

\author{
Lei Xie $\mathbb{D}^{\mathrm{a}, \mathrm{b}}$ and Jeroen Warner (iD)
}

alnstitute of Governance, School of Political Science and Public Administration, Shandong University, Qingdao, China; 'bancaster China Centre, Lancaster University, Lancaster, UK; 'Social Sciences Group, Wageningen University, Wageningen, The Netherlands

\begin{abstract}
Managing transboundary river basins proves a challenge for China when encountering disagreements with its neighbors that experience different political and social conditions. This paper analyzes what happens when China characterizes water as a security issue, examining China's fluid securitization practices, where changes can be identified indicating that the Chinese government values the various water security concerns differently. Two cases are adopted for comparison. In the case of China sharing the Mekong River, the Chinese government has shown a willingness to incorporate more issues found both inside and outside of the water sector. In contrast, in the case of the sharing of the Ganges-Brahmaputra-Meghna, China's security agenda has been limited to the consideration of water availability and has led to military security concerns. The findings indicate that China's water security agenda is not only driven by a concern for water management over specific rivers, but also judgments that incorporate strategic military consideration with regard to countries that they are involved with. The case of China thus suggests that water security is a complex domain that demonstrates competing values and concerns in (de)politicizing water. Therefore, water-related security issues cannot be understood solely from an environmental policy perspective.
\end{abstract}

\section{ARTICLE HISTORY}

Received 18 May 2020

Accepted 28 December 2020

\section{KEYWORDS}

Mekong River; Ganges-

Brahmaputra-Meghna; India; governance; water security; securitization

\section{Introduction}

China is faced with increasing water related challenges. Severe water scarcity is tangled up with a host of other management issues such as water pollution, ecological degradation, and the increased risks and impacts of floods and droughts. China has $20 \%$ of the world's population but only $7 \%$ of global freshwater supplies, meaning it faces certain degrees of environmental vulnerability of river systems, making the country's use of water resources unsustainable (United Nations 2014). Water is unequally distributed across the country, with the North arid and dry. Much of the water-affluent area is located in

CONTACT Lei Xie Email lei.xie@sdu.edu.cn $\mathrm{Q}$ Institute of Governance, School of Political Science and Public Administration, Shandong University, Rm 403 HuagangYuan, Shandong University Qingdao Campus, No. 72 Binhai Rd, Jimo, Qingdao, China 
transboundary basins from which waters flow out of China to its neighboring countries (Varis et al. 2014; Kattelus et al. 2015; Xie and Jia 2018). In China's arid and water-scarce areas, particularly the North China Plain, water scarcity has worsened since late 1990s (Xie 2009; Jia et al. 2014). As the Chinese economy has developed, it has become increasingly water-intensive so much so that maintaining reliable water supplies has become problematic. The eastern and southern central parts of the country face potential water constraints with growth in demand anticipated to rapidly surpass supply due to urbanization and industrial growth (World Bank 2019).

China shares 40 major transboundary watercourses with neighboring countries to the northwest, northeast and southwest. ${ }^{1}$ This situation is complicated by water pollution and climate variability, which have exacerbated regional tensions over water supplies (Ligtvoet et al. 2018). Overall, water supplies are becoming more unstable and incompatible with the increasing demands being made on them by societies undergoing industrialization. These circumstances pose new and complex challenges, including fears of violent conflict over water. Since the 1990s water has increasingly been characterized as a security issue (United Nations 2007; Shermer 2005) and has grown in strategic importance for a number of countries that either share or lack sufficient access to water supplies. Since the 1950s, this has given rise to popular Malthusiandeterminist geopolitical narratives, with water and its mobilization deciding the rise and fall of civilizations (Wittfogel 1957), and water scarcity forcing the hand of geopolitical actors; drought is bound to lead states to capture water resources (Agnew 2011). Water wars have been predicted since the 1980s (see, e.g., Starr 1991 on this important subject), and never really gone away; recently China's infrastructural drive harnessing water on international rivers has been interpreted as the deployment of geopolitical weapons (Sharma 2020). In this reasoning, the Great Himalaya Watershed is set to become an emergent conflict zone between China and India due to conflicting economic ambitions (Agnew 2011).

The underlying assumption of water "insecurity" is often taken as analytically unproblematic; that is, as an objective and static label. (European) security studies, however, have shown that the dynamics of security matter, and that characterizing a particular issue as a matter of security affects how it is treated domestically and internationally (Buzan, Wæver, and de Wilde 1998). The distinction between issues that are categorized as traditional (high-politics) and non-traditional (lowpolitics) security issues has become increasingly blurred. Environmental issues such as water and climate can become subject to "securitization," pronounced life and death issues legitimizing extraordinary measures (Buzan, Wæver, and de Wilde 1998). A dominant perspective in this approach suggests the effects of water securitization are problematic because treating an issue as a security matter tends to produce militarized and state-centered (sovereignty-focused) policy 
solutions, forestalling development (Deconinck 2009) and foreclosing open debate over how best to manage it.

Managing transboundary river basins proves to be a test for China and its neighbors that experience different political and social conditions. China's securitizing its water is characterized by its exporting a Sino-centric water security rhetoric. As a rising superpower located on the upstream of most of its international rivers, the country's water securitizing moves have shown dynamics over time. Transboundary environmental issues, represented by transboundary water sharing, constitute one of the key topics in the debate on China's core interests (Zeng et al. 2015). Referred as "environmental security" (Yu 2006, 152), the water security issue is perceived as low politics, representing a different security concern from military security. However, a fine line distinguishes environmental security from being perceived as a conventional security concern instead of a non-conventional issue, with the former having the potential to being transformed into the latter (Yu and Zhou 2014; Li 2013). However, such a shift, characterized by the politicization of water, is often inexplicitly conducted, as it is largely obscured by the nature of the Chinese nondemocratic political system (Vuori 2008).

At the regional level, such moves are embedded in contrasting values and navigate among competing national interests (Wolf et al. 2005; Gupta et al. 2013). For instance, in Asia, not all social groups have access and are competent to articulate environmental justice activism to effect influence on national government's policies (Williams and Mawdsley 2006). Opposition has arisen against the exploitation of hydropower in large-scale energy projects, though responses vary. Therefore, on national levels, a lack of channels for public participation has obstructed the development of river basin governance (Huber and Joshi 2015). This feature of Asia's water governance has resulted in dubious effects. In some cases, China's policy responses affect the water supplies of downstream nations and have already been a source of significant tension in bilateral relations, such as in the case of sharing the Brahmaputra River (see case study). In others, China's behavior has led to increasing tensions in water governance that leads to the articulation of injustice.

This paper analyzes what happens when China characterizes water as a security issue. For this, we will distinguish water security as a human security development issue (securing water) and as a national security issue (securitizing water), notably in the context of a security framing, i.e. representing water as a matter of urgency and survival legitimizing extraordinary issues - a "military commodity" to be defended, if necessary at the cost of human lives (Messay 2020).

In this article, we aim to examine the following questions: what happens when water is characterized as a security issue? What are the effects of securitizing water? What impact does "securitizing" water have on international relations? We address these questions here by looking at how China approaches 
water security. China's placing water on the security agenda itself has had political effects, since doing so raises the importance of the issue to survival level and leads to a higher allocation of resources to address it. Two cases are adopted for comparison: the sharing of the Ganges-Brahmaputra-Meghna (GBM) river basin between China and India, and the sharing of the Mekong River between China and downstream countries in Southeast Asia. These cases represent two situations where China's approach toward the issue of sharing international river basins is similar, with similar geographical features of the cases, which are in upstream-downstream situations, and where no competition over water quantity exists. In the case of China and India's sharing of the Brahmaputra River, the Chinese government authorities have shown more concerns, and possibly fears, of the consequences of water sharing with India, while in the case over the sharing of the Mekong River, their reactions seem much calmer. Consequently, these have resulted in different levels of security practices.

Data in the empirical section were collected through publicly disclosed information and a limited amount of secondhand literature. For both case studies, first-hand interviews were conducted with government officials, NGOs and scholars in both China and India. Since environmental activists in India generally enjoy greater freedom of expression, more interviews were conducted in India than in China. As for the Mekong region, one of the authors interviewed scholars and government officials from Vietnam, Thailand, Myanmar and Cambodia. The article is structured as follows. The second part reviews a range of definitions of the term "water security." A particular focal point is the possibility of threats in relation to water-related disasters, such as pollution, droughts, flooding and water scarcity. This section also outlines how securitization practices have given rise to uncertainties that may become more complicated when securing environmental issues. The third section examines China's water security and securitization practices. The fourth section analyzes empirical findings to highlight two different security strategies and their implications. In the case of China's securitizing the Mekong River, while there has been securitization, in the sense of resonating with and producing consent in its intended (downstream) audience, the effects were generally considered "positive" sensu Floyd (2007) and Biba (2016). ${ }^{2}$ In contrast, in the Indian case, securitization has had regionally problematic effects which led to a more militarized policy approach. The last section draws tentative conclusions about the rationale behind China's dynamically evolving securitization practices and their implications for international relations. 


\section{Theoretical discussion: water security and securitization dynamics}

Security framing (securitization) is defined by features that represent the "discursive politics of security" (Dillon 1996, 47; Balzacq 2005). The Copenhagen School of security studies (CoS) has argued that security does not refer to something "real" or "external," focusing instead on security as a "political choice" (Waever 2000, 251). For the Copenhagen School, politicization makes an issue part of the domain of (national) politics, while securitization lifts an issue "above normal politics," successfully presenting it as a life-and-death national-security issue. They argue that security comes into being when an elite actor labels a particular issue, an issue of security from a position of authority, and this is accepted by the audience, resulting in a successful "securitization," legitimizing exceptional crisis measures such as secrecy, detention without trial and other forms of ignoring the rule of law. Nuances can be found in the discussion of environmental issues, when concerns focus on protecting the ecology instead of the state, such policy issues are also labeled as nontraditional security concerns that are likely to induce peaceful state reactions. The application of securitization presents special complexities outside Western liberal democracies. Wilkinson (2007) has noted that in authoritarian or otherwise securitized states, it may be difficult for domestic actors to "speak security" (to securitize or de-securitize), thereby setting themselves apart from the state's values. Holbraad and Pedersen (2012) likewise note that in states born out of revolution, state and societal interest are presumed to be one and the same. This convergence promotes a realist, unitary-state approach to Chinese International Relations (see also Vuori 2018).

We now turn to analyzing existing water security debates and their limitations.

\section{Water as a security concern}

The term "water security" is increasingly used in scholarly and policy debates (Cook and Bakker 2012). For an individual community, the main water security concern lies in those related to human needs, covering issues such as access, food security and human development-related concerns (Cook and Bakker 2012). National water security concerns often focus on vulnerability to major water-related hazards and terrorism (Shermer 2005; Cook and Bakker 2012). In times of crisis, such as destructive floods, this may require special treatment (extraordinary measures), such as declaring a state of emergency. In normal times, however, community and national water security can be assumed to be realized through regular means of provision. If the referent objective is rivers, water security has been realized through regular policies that reinforce the management of water resources - without extreme securitization practices. 
When, by contrast, water is discussed in the context of international relations, the potential for conflict and/or violence over water resources has frequently been at the top of the agenda since the 1990s - analytically as well as politically (Dinar 2002). Here, water insecurity is seen as a potential threat to national interests, and a potential casus belli. Radical securitization measures may then be adopted, including the use of violence. Despite dire prediction, however, this is not the only or even most likely scenario. Conflicts over water resources (and on the peculiarity of water as a resource) have been debated extensively, centering on issues including whether water is likely to lead to violent conflict (Homer-Dixon 2010) or cooperation (Wolf 1999), and whether water cooperation leads to regional cooperation (Muller 2015; Warner 2016). Moreover, new security linkages have entered the fray: water, food, energy, climate, and biodiversity. Scholarship has further complicated the debate by advocating the collective securitization of water, food, energy and climate and the identification of substitution options including water for food and water for energy (the "Nexus," Hoff 2011; Allouche, Middleton, and Gyawali 2015).

"Water (in)security" first emerged as a policy concept in the 1990s, both in terms of human security (water poverty) and environmental (in)security, as the stake in predicted "water wars." It was not until 2007 that the United Nations Security Council has declared water a potential security risk (United Nations 2007). Apart from the UN and nation states, active securitizing actors also include international NGOs, river communities and river basin organizations. Globally, conserving rivers and protecting river community interests are established environmental activities that have been widely recognized in policy practices over water management. Such securitizing moves can be understood as "initiatives made in the name of a collective in order to save it from future disaster or extermination seeking to save it from future disaster and extermination" (Jutila 2006, 172). Such efforts are recognized in, for example, environmentalists' protesting hydropower generation. These actors have a good chance to advocating their priority when defining water values and preferred water uses. In addition, a competing security agenda exists for environmentalists. Priorities may be given to sustainability for traditional environmentalists that focus on conservation, while some other environmental NGOs may well focus on defending human interests, such as a river community when resettlement is forced upon them.

\section{Securitizing acts over water}

Environmentally conscious scholars have strongly argued for managing transboundary river basins considering the ecosystem level before state interests (Granit and Joyce 2012). The mismatch of sovereign borders and ecosystem borders creates a tension in the scale at which water is securitized (Warner, Wester, and Hoogesteger 2014). As Agnew emphasizes, state territories are seen 
as fixed units of sovereign space; and sovereignty is to be exercised in all cases (Agnew 1994). In cases where water resources are shared by two or more nations, the emphasis in the scholarly literature tends to fall on the national boundaries in play rather than the geography of the water resources. Competition over scarce water resources is apt to lead to violence and even military action (Zeitoun and Mirumachi 2008). In contrast, cooperation has proved to be a distinctive securitization practice. This is particularly the case when controlling human disasters is placed high on the security agenda. Indeed, when facing disastrous events, such as flooding, it is noted that a desire among nation states to protect human life may lead to environmental peace-making and international cooperation (Conca, Wu, and Mei 2006). However, water securitization may shift out from the environmental (lowpolitics) sector into the military (high politics) sector when it is weaponized. One concern related to shared rivers is that water disasters may become weaponized through the manipulation of hydraulic infrastructure - inciting drought (a resource capture strategy) or flooding when countries deliberately affect the flow or quality of water resources (Gleick 1990).

Another notable aspect of securitization, the security referent, has been constantly changing in the political agenda of security actors. Trombetta points out that in CoS' early work (Buzan 1991), the biosphere has been a main focus. However, human society or "human enterprise" (Buzan, Wæver, and de Wilde $1998,76)$ has become an emphasis that represents the dominant referent object in environmental security (Trombetta 2008). The CoS adopts a rather conservative perspective on securitizing the environment by asserting that "most of the threats are too distant to lead to securitization" (Buzan, Wæver, and de Wilde $1998,83)$. With a shifting focus from nature being the objective of national securitization to global civilization or humankind being the ultimate target for protection, it optimistically deduces that environmental issues do not constitute an existential threat posed to national security (Deudney 1999; Peoples and Vaughan-Williams 2010), and this makes the environmental sector an exception from other sectors. The securitizing of the environment is argued to take place in open debate, which signals regular politics. Trombetta (2008) dismisses such deduction and suggests that the CoS' argument reinforces possibilities for securitizing the environment with radical practices (Edkins 1999). Oels (2012) on the other hand observes a "climatization of security," which causes security practices to be increasingly informed by (human-security) practices in the climate domain, such as resilience. Therefore, with the co-existence of different security concerns, securitization practices of different states are likely to differ from each other.

Apart from the above-identified differences in water values, the issue of how to best conduct effective water management also prove challenging. Nowadays, institutional arrangements managing transboundary rivers primarily rely on experiences learned in the past and the replication of models across 
space. Many well-managed transboundary rivers enjoy a rich history of developing effective institutions and skills (Benson, Jordan, and Smith 2013; Groenfeldt and Schmidt 2013). However, there are no universal institutional arrangements that can be applied in shared river basins. The Convention on the Law of the Non-Navigational Uses of International Watercourses (UN Watercourses Convention or UNWC) has not yet been widely recognized as a framework providing basic provisions on water issues (Salman 2007) - and, crucially, was not signed by China. ${ }^{3}$

Therefore, the water sector has demonstrated a complex nature. Analytically and empirically, practices of securitization processes have shown two remarkable features, in the form of exceptional politics and/or in the form of regular politics.

\section{Water security and securitization in China}

\section{China's water security agenda and domestic securitization}

The politicization of water has been a regular feature of Chinese governance from ancient times before the Qin dynasty (BC 221), when the first centralized polity had been established. Chinese society has demonstrated a clear anthropocentric view that strongly advocates human needs and interests: the government considers the non-human world as subordinate to the interests of human society (Shapiro 2012). Chinese political elites' perception of water features risk aversion in relation to the use of natural resources. Historically, the government has assigned a high priority on its agenda to management of water. China's four-thousand-year history reveals a predominant focus on agriculture and flood control in its governmental approach to water management. Since waterrelated disasters posed a potential threat to regime stability, it was essential for rulers to maintain a good record in managing water including disasters. Governing water efficiently by averting risks brought legitimacy for rulers. Some have even suggested China's political system was built upon the administrative system responsible for managing water-related affairs (Wei 2011). Wittfogel saw China as a clear example of "oriental despotism" (Wittfogel 1957). Wittfogel's thesis, it should be noted, has been widely criticized, or even discredited since then, for its geographic determinism and instrumentalism, without an eye for its political process (Banister 2014). However, his insight that states like China and Egypt have linked control of the environment with social control and centralization remains valid.

Rooted in its long history of cultural and oftentimes religious approaches to water, China has also demonstrated a utilitarian approach to water: water is of different instrumental uses, which include water as a freshwater resource for human well-being, an economic resource that supports agriculture, industries, navigation or energy generation, and the natural environment for fishes and 
aquaculture, which humans also benefit from for food. With the referent object being China's national interest, China has expressed security concerns over water quantity as well as water quality (pollution), with a view to whether economic benefits can be gained from water. To China's central government, water is highly important, in the sense that economic interests can be pursued, while flooding and drought pose threats to human security. China's security concern has also evolved to include water ecology: nowadays China's agenda on water is to ensure that both human needs and river sustainability are prioritized simultaneously. In 2011, the Chinese Communist Party's Document number 1, known as the "Three Red Lines" water policies, stated that: "Promoting the development of water reform is not only important to agriculture and rural development, but also of significance to social and economic development; such reform is important to the prevention of flooding, the security of water supply and food supply, but also essential to the security of economy, ecology and the state." Again, the Chinese authorities' focus in water governance remains the pursuit of national interests, such as through the exploitation of water resources for hydropower, transport navigation and other for-profit uses that are highly encouraged. This broadly meshes with the UN's needs-based definition of water security (United Nations 2013, 1), which is "the capacity of a population to safeguard sustainable access to adequate quantities of acceptable quality water for sustaining livelihoods, human wellbeing, and socio-economic development, for ensuring protection against waterborne pollution and water-related disasters, and for preserving ecosystems in a climate of peace and political stability."

In contrast, China's security concern over international rivers differs. Fears have arisen due to the potential spill-over effects of water security sector into the military sector as a result of China's exploitation of international rivers. This comes from an assumption that countries can wage war over water scarcity, just like they can over territory. This will be elaborated in the section below. ${ }^{4}$

\section{Securitizing water in domestic China}

In China, water management is still monopolized by state authorities that prioritize national interests. In water management, the state retains its monopolizing role in the planning and the development of water policies (Xie and Jia 2018). The government is entitled to define "water rights": the primary concern for regulating water rights is the allocation of and access to water resources (Zhang and Bai 2004). Nevertheless, in China, contention exists on who are legitimate users and what entitlements they have. For instance, the allocation of water supplies between users of water basins (which comes under administrative jurisdiction) is identified as one common type of water dispute, particularly between upstream and downstream users (Chu et al. 2014; Shan 2016). 
Chinese policy debates do not readily incorporate the views of non-state actors. Government authorities alone determine how to approach resource management. China's legal framework has seen rapid developments regarding the scope of laws and the incorporation of public participation (Xie and Xu 2021). Yet this legislation is criticized for not opening up full and genuine public access to official decision-making, and for neglecting to incorporate a clear set of environmental rights for the public (Xie 2015). In practice, there has been little incorporation of public rights and wishes. Such practices have also been witnessed in policy process deciding on domestic infrastructure projects (Johnson 2020).

China's prioritization of water security is explicit in formal documents laying out the Chinese Communist Party and governmental viewpoint on securitizing water. Academic studies of the subject have been dominated by natural sciences and environmental studies (Cook and Bakker 2012). As a result, the existing institutional framework and policy focus has been placed on how to address water supply concerns or how to manage water supplies. Again, taking the example of the Three Red Lines water policies (2011), China advocates "accelerating reforms in water management," by prioritizing water management in societal and economic development. It states that "such reforms are to view water resource management as requiring a strategic approach that is fundamental to the country's sustainable management of water." Principally, in water resource management, government needs to incorporate scientific knowledge and a legal regulatory framework. No enemies are identified in this policy document. Hence, China's water security practices are mostly seen through the prism of normal national politics.

Domestically, the "human (developmental) securitization" of water is mostly successful as current water allows increase in GDP while ensuring food and energy security (Jia et al. 2014). This is related to China's authoritarian environment governance style, where public participation remains limited on key issues. The secrecy of the policy process in China makes it more pertinent to understand what constitutes its water agenda when water becomes a security issue. From the perspective of referent objects, both national and human interests can become a priority. As a result, China's water securitization has seen dynamic changes, a transformation overlooked in scholarly debates.

\section{China's water security agenda over international rivers}

China has manifested a state-centric stance in water management. The Chinese government has, to a limited degree, incorporated water policy tools that are advocated in transboundary water management. For instance, in western Europe, integrated water resource management (IWRM) principles have been advocated since the 1990s, which are considered to recognize the hydrosocial cycle at the basin level among river basins across borders and how different 
actors, including local communities, perceive the wide range of resources needed in the basin (e.g. livelihood options, ecosystem services). However, in China's multi-level governance model, the incorporation of IWRM remains limited and the implementation of IWRM at local levels is lacking, aside from initiatives in large river basins that are led by international non-governmental actors, such as the Global Water Partnership (UN Water Report 2016).

In the case of international river sharing, the Chinese government has intended to transfer domestic policy in the management of international river basins. For instance, as required for domestic water resource management, the Chinese government also advocates that new transboundary river projects must undergo a thorough scientific assessment, with consideration of the interests of both downstream and upstream riparian countries (He et al. 2014). Such projects must also comply with the government's transboundary environmental impact assessments (TEIA), which are viewed as an important principle in the UNWC (He et al. 2014). However, in practice, compliance to these rules proves challenging (Zha 2014). China's ministry of foreign affairs, the main government unit responsible for the matter is lacking in international platforms to contact its foreign partners including those at national and local levels to comply with the proposed environmental impact assessment norms (Xie and Jia 2018).

In addition, water security concern over international rivers is perceived slightly differently in China. On the one hand, the Chinese discourse on environmental security views ecological threats the same way as in western Europe, where environmental security represents a separate category of threat (Boas 2014) and is understood to feature low-politics (Xie, Zhang, and Panda 2017; Xie and Jia 2017). On the other hand, in considering its power balance with its neighbors, the Chinese government and its securitizing actors have the tendency to associate regular politics with more traditional security concerns such as territory and sovereignty. In other words, China's water security agenda is not only driven by concerns for water management over specific rivers, but also judgments that incorporate strategic military consideration from the military sector with regard to countries that China is involved with. Following this line of logic, China's international water security agenda, and its securitization attempts over international rivers, become rather fluid and its effects uncertain. We will therefore distinguish features of China's securitization practices, which are in the form of exceptional politics and/or in the form of regular politics; and further investigate under what conditions such a shift might occur.

\section{Methodology}

Our study is based on the analysis of various discursive texts ranging from political statements and speeches to media coverage, and two field investigations that collected over 21 hours of 13 semi-structured interviews among key stakeholders (including diplomats, state officers, scholars, and NGOs) conducted 
between 2014 and 2019 (see Table 1). Documents, policy paper as well as media briefings have been collected from state sources.

\section{Empirical findings}

\section{Contextual factors of cases}

The study selects two case studies of China's water policy as it is applied to various international rivers and neighboring countries: these are the GangesBrahmaputra-Meghna (GBM) river basin (shared with India and Bangladesh) and the Mekong River basin (shared with some of the ASEAN countries). Both cases see China located immediately upstream on the shared river system, a specific geographical feature that challenges countries' negotiations over shared water resources. However, the Mekong and GBM river basins exhibit very different geographical factors and conditions (Table 2), which may strongly impact how countries negotiate over shared rivers (Ovodenko 2016). The Mekong River was eyed by China as a site for development projects in the late 1990s, about two

Table 1. Interviewees' information.

\begin{tabular}{|c|c|c|c|c|}
\hline Participants & Gender & $\begin{array}{l}\text { Age } \\
\text { group }\end{array}$ & Location & Occupation \\
\hline Interview 1 & M & $40-50$ & Beijing, peking & Professor in International Relations, University \\
\hline Interview 2 & M & $30-40$ & $\begin{array}{l}\text { Shanghai, } \\
\text { SASC }\end{array}$ & $\begin{array}{l}\text { Research Professor in International Relations, Research } \\
\text { institute }\end{array}$ \\
\hline Interview 3 & M & $40-50$ & $\begin{array}{l}\text { Phone } \\
\text { interview }\end{array}$ & NGO \\
\hline Interview 4 & M & $40-50$ & Beijing & Professor in Hydrology, Research institute \\
\hline Interview 5 & M & $50-60$ & Shanghai, & Professor in IR, University \\
\hline Interview 6 & M & $50-60$ & Shanghai, & Professor in IR, Research Institute \\
\hline Interview 7 & M & $30-40$ & New Delhi & WWF India \\
\hline Interview 8 & M & $20-30$ & New Delhi & International Rivers, India \\
\hline Interview 9 & M & $50-60$ & New Delhi & Professor in IR, University \\
\hline $\begin{array}{l}\text { Interview } \\
10\end{array}$ & M & $60+$ & New Delhi & Retired government official \\
\hline $\begin{array}{l}\text { Interview } \\
\quad 11\end{array}$ & M & $30-40$ & New Delhi & Professor in IR, Research Institute \\
\hline $\begin{array}{l}\text { Interview } \\
12\end{array}$ & M & $30-40$ & Beijing & Diplomat in Ministry of Foreign Affairs, China \\
\hline $\begin{array}{c}\text { Interview } \\
13\end{array}$ & M & $30-40$ & Beijing & Diplomat in Ministry of Foreign Affairs, China \\
\hline
\end{tabular}

Table 2. Geographical and population information.

\begin{tabular}{lcc}
\hline & Mekong & GBM \\
\hline Riparian countries involved & $\begin{array}{c}\text { Vietnam, Cambodia, Laos, Thailand, } \\
\text { Myanmar and China } \\
58,694,130\end{array}$ & $\begin{array}{c}\text { China, Bangladesh, India } \\
\text { and Bhutan } \\
162,448,992\end{array}$ \\
$\begin{array}{l}\text { Basin scale population in all riparian } \\
\text { states (2010) }\end{array}$ & $26 \%$ & $13.1 \%$ \\
$\begin{array}{l}\text { Percentage of basin belonging to } \\
\text { China }\end{array}$ & & \\
\hline Source: Yan (2017). Water security in China's transboundary rivers. Doctoral thesis. Chinese Academy of Sciences.
\end{tabular}


decades earlier than it eyed the GBM. Although China is upstream in each case, the Mekong's situation is much more complicated than that of the GBM, both in terms of the number of countries it runs through and the river run-off from each state.

Although in each case China is not in acute competition over water quantity, its relations with other riparian states over water usage are different with regard to water sharing. In the Mekong case, China represents notably different asymmetric uses relative to those of the Lower Mekong Countries. On the GBM, however, China and India have much in common in regard to water sharing, including the extent of their political power and the importance of their actions to their immediate downstream neighbors. From this perspective, China and India make a similar impact upon the GBM. Nevertheless, China has employed a different securitization process that has led to different outcomes. Comparison of these two cases can shed light on the rationale underlying China's securitization of water.

\section{Case I: China promotes extensive river exploitation on the Mekong}

The Mekong River, known as the Lancang in China, is at the heart and soul of mainland Southeast Asia. It traverses the six riparian countries of the Greater Mekong Sub-region (GMS), comprising Vietnam, Cambodia, Lao PDR, Thailand, Myanmar and China. China originally sees the sharing of the Mekong River a matter of regional geopolitical competition (Bi 2013), instead of a separate issue of its own right. Scholarship suggests that the Beijing government aims to develop good-neighborly diplomacy (Ruan 2014), which is characterized by the primary goal of maintaining a peaceful peripheral environment for its economic growth and political stability. China aims to continue exploring the economic values from the shared Mekong River. Emphasizing water's economic benefits instead, China has adopted a series of plans to generate income by building dams over the Mekong River. Since the late 1990s, Chinese investment has grown in terms of total investment in hydropower development in the LMR. These include not only unilateral construction of dams in Yunnan province but also collaborative initiatives with Laos and Cambodia on the upper range of the Mekong. ${ }^{5}$

However, various actors in the Lower Mekong Countries have shown concerns linked to China's various development plans, with the foremost being China's damming activities. It is feared that damming projects have impacted both qualitatively and quantitively, on the environment. The downstream channel may scour, thereby becoming unstable, and the environmental impact of large-scale dams is argued to be destructive to the ecology of the river in downstream countries (Mehtonen, Keskinen, and Olli 2008), where the aquatic environment is destroyed (Kondolf, Rubin, and Minear 2014). Concerns have also been raised that China's dam construction on the Mekong River may be 
responsible for aggravating flooding or drought conditions (MRC 2020a). China is assumed to be in a strong position to exert its military powers over the Lower Mekong Countries through flooding, given that the capacity of the dams can directly impact disastrous events that Lower Mekong Countries may experience. Hydropower construction projects raise concerns on Chinese investments, as the control of the projects lies with Chinese companies for a long time before they are transferred back to national authorities. And the financial operation of such projects is complicated by the fact that the Chinese government, executed by its state-owned enterprises, bundles aid, trade and investments. This reduces host countries' control over water management (Urban, Siciliano, and Nordensvard 2018).

There are also concerns about impacts on fisheries resource have already emerged (Kittihoun and Staubli 2018), fearing that fish habitats and their migration and breeding cycles could be irreparably altered and possibly destroyed, thereby reducing productivity and greatly impacting biodiversity (Roberts 2004; Baran and Ratner 2007; Feng et al. 2019). This factor links to concerns over livelihood security as millions of the residents rely on fisheries for their livelihood (Kittihoun and Staubli 2018). Dam construction is argued to generate social injustice in the region (Dore 2014). Apart from the Lower Mekong Countries, the UN has become another securitizing actor on the issue of Mekong River Basin management. Its agenda is mainly concerned with water sustainability. In May 2009, a report by the United Nations Environment Programme (UNEP) warned that China's plan for a cascade of eight dams along the Mekong River might pose "a considerable threat" to the river and its natural riches (UNEP 2009).

Environmentalists in the Lower Mekong Countries also constitute another important securitizing actor. The Beijing government has become concerned about discontent among the Lower Mekong Countries with its unilateral actions and damming policies. Opposition has arisen against the exploitation of hydropower and large-scale energy projects. Aiming to enhance waterway safety, in 2000, China agreed to the Commercial Navigation on the Mekong-Lancang River with Laos, Myanmar and Thailand to jointly survey the Mekong River basin to ensure that any navigation project is well designed and monitored. ${ }^{6}$ The agreement primarily aims to guarantee that China benefits from the shared river for profits gained from commercial navigation while ensuring its safety. It is mentioned that such activities should consider reducing negative environmental impacts; however, there is a dearth of elaboration how this can be achieved. The agreement has also enabled "blasting rocks and rapids in the Mekong," worrying environmentalists that the fragile ecosystem would be further destroyed and the project would only benefit China (Biba 2018, 628). After a decade of campaigns, Thai government had halted the project, as a result of oppositions raised by local residents and environmentalists (International Rivers 2020). Although the roles that NGOs played in advocacy have been tangible 
(Simpson and Smits 2018), such articulation has significantly impacted on Chinese government's implementation of its water exploitation activities. ${ }^{7}$ The Chinese government 'had become more alerted of the influence of environmentalists in these countries (when promoting its infrastructure project). ${ }^{8}$

China has become aware of tensions arising from Lower Mekong countries over China's uses of the shared river. As a result of challenges posed by various securitizing actors, China had responded by shifting securitization approach toward adjustment of its water security agenda and gradual open inclusive discussions when exporting its water security agenda in the Mekong region.

For China, the Mekong region represents strategic interests for its economic growth as well as political stability. Beijing not only reckoned water had become a contentious matter but also decided it did not want to risk losing its influence in the region, especially to other regional forces, such as the US and Japan. The United States and Japan are putting all their diplomatic forces into a so-called free and open Indo-Pacific (FOIP) strategy, co-opting Japan, US, India, Australia, ASEAN, European and Middle Eastern countries, for connectivity in infrastructural development in Southeast Asia, Southwest Asia and East Africa - a strategy that directly challenges Beijing's "Belt and Road Initiative" (BRI) initiative. Washington reiterated its commitment to increase law enforcement capacity in the Mekong region through ministerial meetings (Gong 2020). Some ASEAN countries, such as Vietnam, because of their differences with China on the South China Sea issue, have shown support for the free and open Indo-Pacific proposition and the future development of the Indo-Pacific strategic alliance. The newly signed Regional Comprehensive Economic Partnership has the potential to further strengthen China's relations with neighbors (Petri and Plummer 2020). Japanese official discourse has constantly linked "Indo-Pacific" and "International Public Goods," increasingly positioning the "Indo-Pacific Ideas" as a means of providing international public goods and highlighting its public welfare (Lu 2019).

From a realization that unilateral actions over the shared rivers would not be constructive for long-term national strategic interests, China's acts to promote water security had been expressly noted to develop good-neighborly diplomacy (Shi 2013; Ruan 2014; Shen and Xie 2018), for the country to be accepted as an important partner on issues relating to the uses of the shared river basin and water management. China has also shown transformation in its security practices: China "disarmed" the securitizing move by making unprompted unilateral data-sharing and transparency moves and entering into dialogue with the downstream countries (Biba 2016) and Beijing has started to develop open debate among the Lower Mekong Countries. While the Chinese government expressed its intention to provide more humanitarian assistance in protecting citizens of both China and Lower Mekong Countries from environmental harm and natural disasters, ${ }^{9}$ the nature of such debate was to, for the time being, pacify Lower Mekong states sharing the river. 
China's desecuritizing rhetoric presents water security as "non-conventional" (China Daily 2018). Our interviews indicate that the Chinese government is now keen to be seen as a responsible actor, and taking measures to win a positive image in the region. China's declared water security agenda of the Lower Mekong Countries is constituted by "low-politics" concerns such as human disaster, human needs (especially food) and water sustainability. China has advocated for a "river community" on the Mekong and has shown willingness to engage and increase transparency - but notably, on its own terms. Being a Dialogue Partner of the Mekong River Commission (an intergovernmental organization established among riparian states in the Mekong River basin), China has notably declined to actively engage in dialogs and in effect, has routinely declined to consult riparian neighbors over its planned interventions (Biba 2018). ${ }^{10}$ Instead, China made a considerable effort to convince the Lower Mekong Countries to join a new institutional mechanism: the Lancang-Mekong Cooperation Mechanism (LMCM). To Chinese diplomats, this is not a scheme that centers on water management. "LMCM is rather a regional cooperative mechanism. At its preliminary stage, LMCM did not have to primarily focus on water management." ${ }^{11}$ But of course, it would inevitably touch on water management at some point.

Through the LMCM, China has intended to promote a collective mechanism for the riparian countries to deliberate a common strategy for mutually shared benefits. These include institutional building to incorporate ministerial officials from all five riparian states which regularly convene on actions plans over the shared river. Special commissions have also been set up to discuss work on the key areas identified, ${ }^{12}$ which are including "connectivity, production capacity cooperation, cross-border economic cooperation as well as agriculture and poverty-reduction cooperation."13 Under this scheme, Beijing has promoted inter-sectoral and intra-sectoral link with the water sector. The priority areas of cooperation within the LMCM cover a broad range of issues that have inter- and intra-links with water management. ${ }^{14}$ Beijing has promoted intersectoral links under the LMCM, which include infrastructure development, trade and economic opportunities as well as environmental protection projects with its

Table 3. Inter- and Intra-sectoral linkages with the water sector within LMCM.

\begin{tabular}{|c|c|}
\hline Country & Cooperation projects with China \\
\hline Thailand & Airport construction; Rice cultivation, animal husbandry forage acquisition, sustainable agriculture \\
\hline Cambodia & $\begin{array}{l}\text { Hydropower construction, electricity generation station building, trade on agriculture, water } \\
\text { resource management, lake and water ecology protection }\end{array}$ \\
\hline Laos & $\begin{array}{l}\text { Bridge, hydropower and railway construction, Stocking of juvenile fish in water courses, } \\
\text { biodiversity protection, tourism }\end{array}$ \\
\hline Myanmar & Oil pipe and hydropower construction, poverty-relief, agriculture and irrigation \\
\hline Vietnam & City railway construction, trade and investment, tourism \\
\hline
\end{tabular}

Source: Information collected from Feng et al. (2019); and Lancang-Mekong Cooperation Mechanism, official website, http://www.Imcchina.org/sbhz/t1628002.htm 
riparian neighbors. These are mostly based on bilateral cooperation between China and individual riparian states (see Table 3).

Since August 2020, the Chinese government has pledged to share year-round hydrological data with the Mekong countries (Mekong River Commission 2020b). China has also attempted to prove through scientific findings that its dam construction projects will not have the claimed negative effects. It has also carried out joint research project to prove its dams not being a cause for disasters in the downstream, though to limited success (MRC 2016). Furthermore, China has also aimed to promote technological knowledge transfers. Beijing has expressed a keenness to enhance Lower Mekong Countries' capacity building in this regard (Ministry of Water Resources 2017). China has developed a strong capacity in the provision of aid and technological assistance to countries through international cooperation (Urban et al. 2015), which has appeared a weakness in the Mekong River Commission (MRC). Both the Ministry of Environmental Protection and Chinese Ministry of Water Resources have led training and workshops to share its know-how and management experiences on flood prevention with the MRC and professionals from individual Lower Mekong Countries (Xinhua News 2011; Dali Daily 2018).

China's leveraging of water security over the Mekong River basin has proved effective, although such acts prioritized state and international actors. Since most Lower Mekong Countries perceive water resources primarily as sources of income, they have largely approved of China's policy design and conducted some intra (inter-water) link in water cooperation.

\section{Case II: China's accelerated policy on the Ganges-Brahmaputra-Meghna (GBM) river basin}

China and India have a long-running border dispute centered around SouthTibet (known as Arunachal Pradesh in India), a region located downstream on the GBM Basin in north-eastern India. The sharing of the GBM has shown that both China and India have developed incompatible security agendas. Subsequently, China's securitization practices are also evolving from regular politics to radicalizing water security.

China's security agenda had been rather simple by focusing on human disaster, following flash floods that have regularly caused large-scale destruction in South-Tibet (Arunachal Pradesh). Having closely monitored the situation for weeks beforehand in 2000, the Chinese authorities sent warnings to the Indian government about the likelihood of landslides. Subsequent talks on the issue between the two nations led to an agreement over the Brahmaputra River. In 2002, a Memorandum of Understanding was signed that requested China to provide annual hydrological information on the Yaluzangbu/Brahmaputra River in flood season. ${ }^{15}$ 
China engaged unilaterally in 2000 by warning India of ecological disasters. This move helped the two countries to develop water diplomacy around the issues of "natural disasters' ${ }^{16}$ and "emergency management" (Ministry of External Affairs 2014). Regarding mechanisms of cooperation, after a few years of China unilaterally providing information, a Joint Expert Level Mechanism (JELM) was set up at a ministerial level. ${ }^{17}$ This mechanism provides a platform for communication to take place, where cooperation has been limited to hydrological information provision. With respect to the established mechanism, compliance with the Memorandum of Understanding as well as to the Joint Statements, had been positive. Until 2018, annual meetings of the JELM had been held, except for 2017 when the Doklam military standoff over the Chinese construction of a road in territory disputed by India took place (PTI 2019). These meetings have led to a better understanding of the data, such that they can be used by the Indian authorities to formulate flood forecasts (Ministry of Water Resources 2014).

When queried on China's upstream activities, based on its understanding of the river characteristics, the Chinese authorities emphasized that they had explored the river without constraining the Indian side. As the Indian official responses have shown, China's dam construction is "[a] run-of-the-river power project which does not store water" (Mehdudia 2011). China claims that its dam construction projects on the upstream of the Brahmaputra have very little impact on India, particularly in the remote and sparsely populated region of South Tibet (Arunachal Pradesh), through which the river flows. Such framing also aims to convince India that China's activities over the shared resources do not affect the Indian side's enjoyment of benefits. Nevertheless, the Chinese authorities and its diplomates have been cautious about the sharing of the Brahmaputra River. To them, water sharing is viewed both as environmental security and a sovereign issue because the rivers are geographically located near a disputed borderline (Yu and Zhou 2014; Dong 2014).

Subsequently, since around 2010, China has accelerated its exploitation of the economic potential of this region through resource governance. As technological development has become more readily available, China has been keen to make use of the Brahmaputra River system, which has been viewed as "under-exploitation" by both China and India (Jia et al. 2014). In both the $11^{\text {th }}$ five-year plan (2007-2012) and 2012's five-year plan (2013-2017), provision was made for the development of South West China, including through the Zangmu dam and further proposed dams on the Yalong, Dadu and Nu Rivers. Led by Chinese environmentalists, there were vociferous protests against all these projects both within and outside China, with concerns of preserving the ecological rivers that had not been dammed. The Zangmu dam, which is located on the middle reaches of the Yaluzangbu River and generates 510 megawatts, began operating in 2014. The total contribution of the Zangmu dam, in 
particular, is equivalent to the entire previously existing hydropower-generating capacity of Tibet.

China has focused on managing water resources for its economic benefits. However, little scientific evidence was provided to show how the Indian government had made a wrong judgment. Indeed, China's politicization had proved successful. Beijing was pleased with India's responses to its diplomacy during the period of Singh's government (2004-2014) in India. In particular, in an official statement from 2011 the Indian national authorities clarified:

We trust but we also verify. We have verified Chinese claims on the dam being [a] runof-the-river power project which does not store water. We are convinced that it is a runof-the-river project (Mehdudia 2011).

India's security agenda has evolved from focusing on human disaster to incorporating broader concerns, including water availability. India and China compete vigorously for power regionally and globally. India has also shown its intention to exploit water resources in the shared river. India, as a downstream country also plays a competing role in order to benefit from the shared water resources. Overshadowed by China's technological development and rapid advances in dam construction, India has lagged behind in its dam construction and, according to an Indian interviewee, felt bitter about China taking the lead in profiting from the shared water resources. ${ }^{18}$ Interestingly, in the case of Brahmaputra management, domestic and international NGOs in India had been relatively silent on Sino-Indian water sharing issue. According to interviewees, the management of the Brahmaputra has been branded a domestic issue, "the use of the river is most affected by domestic policy than by China on the upstream. The geographical location of the river makes it replenished in monsoon season, so water quantity competition between the two countries exists, it stays only as a temporary issue." This also explains that their activities primarily focus on domestic issues, including educating the public and influencing the Indian government to clean the river, enhancing pollution control and opposition on the development of large-scale hydroelectricity projects in the Indian part of the river. ${ }^{19}$

Following a wave of public concern raised against China's dam construction projects on the upstream of the GBM, the Modi government has shown no signs of accepting the Chinese government's diplomatic explanations. Instead, the Modi government presses for all-year hydrological data. For the Beijing government, in a situation where no water competition exists, Modi's gesture signals that the issue of water availability is incorporated in India's security agenda. With India's security agenda transformed, Modi might take radical securitization actions that result in military measures being adopted. ${ }^{20}$ Modi has already repeatedly threatened water capture on the Indus River shared with Pakistan (Rigi and Warner 2020). Such interpretation has made the Chinese government feel that its sovereign right over water resources is being violated. To Chinese 
scholars and officials representing domestic securitizing actors, the Indian government and political elites had constituted key securitizing actors that mobilized media campaign to purposefully politicize the water issue by portraying it as national security issue (Jiang et al. 2017). The Indian securitization frame is viewed by the Chinese government as fueled by nationalist sentiments and thus Beijing had become more convinced of its securitization acts being legitimate.

China's subsequent securitization actions over the GBM have therefore led to the adoption of coercive politics. In 2017, Indian and Chinese troops were mired in a long-standing face-off at Doklam. A mutual "disengagement" only occurred just before the two national leaders were to meet in Xiamen, probably with an intention to avoid a total rupture in their foreign relations. When foreign relations between the two countries had become unstable due to military friction developing between the two countries, China went further by putting on hold the sharing of key river data and disregarding the Indian side's call for cooperation to prevent flash floods. As a result, India was left struck by flooding. Thus while China refrained from actively linking the Doklam tensions with the water issue (Ho, Qian, and Yan 2019), India sustained a water security "fall-out."

\section{Assessment of China's securitization of water}

The empirical data provides rich materials to understand the politics of China's water security. China's case indicates that security agendas are dynamic and may lead to different securitization outcomes. Initially, the Beijing government displayed a consistent security agenda in both cases. With a focus on addressing human disasters, China has aimed to contain tensions over water and retained trust with its neighboring states. Such intention was believed to avoid China's regional image in the region of Southeast Asia being damaged in the case of the sharing of the Mekong; and the breaking of peaceful relations with India in the case of the sharing of the GBM. Such an agenda is based on how China traditionally values water. China has demonstrated a rather narrow international approach, compared with its domestic water security agenda, which incorporates both human needs and water sustainability.

When exporting its domestic securitization practices, China's security agenda had been challenged. However, China reacted differently and the subsequent securitization outcomes differed dramatically in the two cases studied. In the Mekong case, the Chinese government has shown a willingness to incorporate more issues in the water sector and outside of the water sector. In contrast, in the case of the sharing of the GBM, China's security agenda has been limited to the consideration of water availability and then led to military security concerns.

Security studies have shown the dynamics of security matter, and that characterizing a particular issue as a matter of security affects how it is treated. This article contends that the ways in which water is included on the security agenda has evolved. Incompatible perceptions of water security agendas do not 
necessarily determine how water is treated, as they constantly evolve. In other words, water can be placed on a security agenda in different ways and with differing outcomes. In the case of China's sharing the Mekong River with the Lower Mekong Countries, the country's water securitization approach has triggered discussions, which have raised China's awareness of the different perceptions that the Lower Mekong Countries have shown in water sector. China may be exporting its securitization experience to the region but had to adjust its water security agenda and allow the Mekong experience to color its domestic securitization experience and discourse. Political authorities may well see those events as now-or-never opportunities to turn dangerous situations into profitable or beneficial political assets (Warner 2004). In comparison, China has adopted military measures for securitization when sharing the GBM with India. This is due to China's determination in narrowing its concerns solely to water disasters, but cannot be divorced from China's geopolitical rivalry with its Indian neighbor. A simple explanation would be that in the two cases, China's primary concern on water availability has been challenged to different degrees. In the case of sharing the GBM, the lack of a diverse range of security actors, so the security agenda advocated by the dominating securitizing actors, which are the state and few political elites, had also strengthened the impression of secrecy. As an essential competitor in its access to water, the Beijing government feels challenged on this aspect, hence its reaction with radical measures. In addition, the geography of water resources also plays a crucial role in the outcomes of China's actions on water. As previously demonstrated, when a shared river is also a national boundary, river sharing is more likely to raise conflicts between countries (Rai, Sharma, and Lohani 2019). The geography of the GBM strongly impacted China's imposing its water security agenda and adopting extreme securitization practices.

The findings from this article warn us that water security is a complex domain that demonstrates competing values and concerns in (de)politicizing water. The changes identified in China's water security agenda indicate that the Chinese government values the various water security concerns differently. Apart from a basic consideration of human disaster prevention, the Beijing government has prioritized national development interests (the "hydraulic mission") over human needs or the sustainable development of shared rivers. Profiting from water resources to boost national income is the most important outcome sought, making it essentially "low politics." "Benefit-sharing" in transboundary river basins is not fundamentally at odds with this striving. At the same time, a strong territorial character is displayed in the region, and water availability is viewed as closely linked to national interests, making river sharing a key "high politics" concern to the sovereign state. In this sense, water can seem more complicated than other environmental issues and can be overshadowed by security concerns that lead to negative effects (Deconinck 2009). 


\section{Conclusion}

Water is multi-faceted, and how it is used is more likely to vary according to the geography and actors involved. Although each county is likely to perceive water differently, their water security agenda is likely to flexibly evolve responding to domestic and international policy environment. This is particularly apparent in the international arena where countries that share water resources differ in terms of their capacities, identities and historical relations with other riparian states.

Despite the conventional wisdom that China is a hegemonic actor monopolizing water security agenda on shared rivers, this study suggests nuances when investigating China's politicizing of water. The empirical findings indicate that China has shown flexibility in adapting its water security agenda. Similarly, its water securitization is not monolithic; different rationales and goals may inform it. "Positive securitization" in Biba's (2018) sense can produce or involve successful water management. The case of China indicates that the source of negative effects from securitization lies in the country's initial refusal to adjust its water security agenda. On the one hand, China's securitization is characterized by ambiguity and secrecy (Trombetta 2008, 11). On the other hand, the politics of securitization alerts us that China's reactions had also resulted from India's politicization of water. The Indian government had continuously dealt with China on a bilateral basis, limiting the disclosure of information on the sharing of the GBM. This way of politicizing water has prevented the involvement of international securitization actors, limiting the opportunities for both countries' water security agenda being challenged. ${ }^{21}$ In so doing, China's securitization practices had turned negative and have dire impacts on the well-being of itself. Noting different trajectories of détente (security de-linkage on the GBM versus "textbook" (Biba 2018) de-securitization on the Mekong), we suggest that in the transboundary water domain, China's water securitization process is highly dynamic which has the effects of impacting its water security agenda.

\section{Notes}

1. These neighbors are Afghanistan, Bangladesh, Bhutan, Cambodia, India, Kazakhstan, Kyrgyzstan, Laos, Mongolia, Myanmar, Nepal, North Korea, Pakistan, Russia, Tajikistan and Vietnam.

2. While the Copenhagen School generally sees securitization as negative in light of the real risk of militarization and secrecy, securitization can be a positive outcome if it helps the speedy resolution of a pressing issue. Whether this resolution is "positive" for all concerned (at all levels) is a different matter.

3. Despite being opened in 1997 following a vote by 103 countries, it took very long for countries to actually sign this convention. It was not until 2014 that this convention was ratified by 35 countries, endorsed by the General Assembly of the United Nations and officially entered into force as a global legal document on transboundary water management. China is one among three countries (along with Turkey and Burundi) that voted against the adoption of the convention at the UN General Assembly. 
4. Interview with China-based scholar of International Relations, June 2016.

5. The Chinese company undertook the construction of the Sanghe II Hydropower Station and put it into operation, 9 January 2019, Lancang-Mekong Cooperation Mechanism, official website, Accessed 10 December 2020. http://www.Imcchina.org/sbhz/t1628002. htm; the Mekong Infrastructure Tracker Dashboard, Accessed 18 December 2020. https://www.stimson.org/2020/mekong-infrastructure-tracker-tool/

6. See Mekong River Commission's introduction on its Navigation program, Accessed 10 December 2020. http://www.mrcmekong.org/about-mrc/programmes/navigationprogramme/

7. Interview with government officials from the Chinese Ministry of Foreign Affairs, May 2016.

8. Ibld.

9. Interview with government officials from the Chinese Ministry of Foreign Affairs, May 2016.

10. China has since 2002 provided the MRC Secretariat with daily water level and rainfall data from two Lancang River hydrological stations at Yunjinghong and Man'wan during the flood season from 15 June-15 October each year.

11. Interview with Officer from the Chinese Ministry of Foreign Affairs, September 2019.

12. Lancang-Mekong Cooperation Mechanism, official website, Accessed 18 December 2020. http://www.Imcchina.org/

13. First Foreign Ministers' Meeting on Lancang-Mekong River Cooperation Held LancangMekong River Cooperation Mechanism Officially 12 November 2015, Accessed 18 December 2020. http://www.fmprc.gov.cn/mfa_eng/zxxx_662805/t1315515.shtml

14. Ibid.

15. It is agreed that China provides India with information of water level, discharge and rainfall frequently (twice a day from June 1 st to October $15^{\text {th }}$ ) each year in respect of three hydrological stations situated on the mainstream Brahmaputra river.

16. On 23 October 2013, the Border Defense Cooperation Agreement (BDCA) was signed between China and India.

17. The Indian side is led by the Commissioner, Ministry of Water Resources, while in China, it is led by Director, International Economic and Technical Cooperation and Exchange Center, Ministry of Water Resources, People's Republic of China.

18. Interview with Indian elite, May 2014.

19. Interview with staff from WWF India, International Rivers India, April, 2014.

20. Interview with Chinese scholar of International Relations, June 2017.

21. Interview with Indian scholar, October2020.

\section{Acknowledgments}

The authors would like to thank Jonna Nyman and the anonymous reviewers for their invaluable comments and suggestions.

\section{Disclosure statement}

No potential conflict of interest was reported by the authors. 


\section{Funding}

This research was supported by Shandong University, funding number 61060089963026.

\section{ORCID}

Lei Xie (ID) http://orcid.org/0000-0002-4535-7893

Jeroen Warner (iD) http://orcid.org/0000-0003-2847-8770

\section{References}

Agnew, J. 1994. "The Territorial Trap: The Geographical Assumptions of International Relations Theory." Review of the International Political Economy 1 (1): 53-80. doi:10.1080/ 09692299408434268.

Agnew, J. 2011. "Waterpower: Politics and the Geography of Water Provision." Annals of the Association of American Geographers 101 (3): 463-476. doi:10.1080/00045608.2011.560053.

Allouche, J., C. Middleton, and D. Gyawali. 2015. "Technical Veil, Hidden Politics: Interrogating the Power Linkages behind the Nexus." Water Alternatives 8 (1): 610-626.

Balzacq, T. 2005. "The Three Faces of Securitization: Political Agency, Audience and Context." European Journal of International Relations 11 (2): 171-201. doi:10.1177/1354066105052960.

Banister, J. 2014. "Are You Wittfogel or against Him? Geophilosophy, Hydro-sociality, and the State." Geoforum 57: 205-214. doi:10.1016/j.geoforum.2013.03.004.

Baran, E., and B. Ratner. 2007. "The Don Sahong Dam and Mekong Fisheries." World Fish Center. Accessed 18 December 2020. https://www.worldfishcenter.org/content/donsahong-dam-and-mekong-fisheries

Benson, D., A. Jordan, and L. Smith. 2013. "“'Is Environmental Management Really More Collaborative? A Comparative Analysis of Putative 'Paradigm Shifts' in Europe, Australia, and the United States." Environment \& Planning A 45 (7): 1695-1712. doi:10.1068/a45378.

Bi, S. 2013. "Participation of Major Countries in Mekong Basin Development Cooperation: Congestion or Coordination?" Journal of International Security Studies 31 (2): 58-73.

Biba, S. 2016. "From Securitization Moves to Positive Outcomes: The Case of the Spring 2010 Mekong Crisis." Security Dialogue 37 (3): 299-318.

Biba, S. 2018. "China's 'Old' and 'New' Mekong River Politics: The Lancang-Mekong Cooperation from a Comparative Benefit-Sharing Perspective." Water International 43 (5): 622-641. doi:10.1080/02508060.2018.1474610.

Boas, I. 2014. "Where Is the South in Security Discourse on Climate Change? An Analysis of India." Critical Studies on Security 2 (2): 148-161. doi:10.1080/21624887.2014.905295.

Buzan, B. 1991. People, States and Fear: An Agenda for International Security Studies in the PostCold War Era. 2nd ed. Harvester: Hemel Hempstead.

Buzan, B., O. Wæver, and J. de Wilde. 1998. Security: A New Framework for Analysis. Boulder, London: Lynne Rienner Publishers.

China Daily. 2018. "Five-Year Plan of Action on Lancang-Mekong Cooperation (2018-2022)." January 11. Accessed 18 December 2020. http://www.chinadaily.com.cn/a/201801/11/ WS5a56cd04a3102e5b17374295.html

Chu, Y., K. Hipel, L. Fang, and H. Wang. 2014. "Systems Methodology for Resolving Water Conflicts: The Zhanghe River Water Allocation Dispute in China." International Journal of Water Resources Development 31 (1): 106-119. doi:10.1080/07900627.2014.933096. 
Conca, K., F. Wu, and C. Mei. 2006. "Global Regime Formation or Institution Building? The Principle Content of International River Agreements." International Studies Quarterly 50 (2): 263-285. doi:10.1111/j.1468-2478.2006.00402.x.

Cook, C., and K. Bakker. 2012. "Water Security: Debating an Emerging Paradigm." Global Environmental Change 1 (22): 94-102. doi:10.1016/j.gloenvcha.2011.10.011.

Dali Daily, 2018. "Disaster Prevention Technical Training Workshop Held in Yunnan." December 18. Accessed 18 December 2020. http://m.yunnan.cn/system/2018/12/18/ 030140837.shtml

Deconinck, S. 2009. Security as a Threat to Development: The Geopolitics of Water Scarcity in the Nile River Basin. Brussels, Belgium: Center for Security and Defence Studies, Royal High Institute for Defence.

Deudney, D. 1999. "Environmental Security: A Critique." In Contested Grounds: Security and Conflict in the New Environmental Politics, edited by D. Deudney and R. Matthew, 187-222. Albany: State University of New York Press.

Dillon, M. 1996. "Governing Terror: The State of Emergency of Biopolitical Emergence." International Political Sociology 1 (1): 7-28. doi:10.1111/j.1749-5687.2007.00002.x.

Dinar, S. 2002. "Water, Security, Conflict, and Cooperation." Sais Review 22 (2): 229-253. doi:10.1353/sais.2002.0030.

Dong, F. 2014. "India's Practice of Settling Trans-boundary River Conflicts in South Asia and Its Influence on Sino-India(n) Transboundary Water Conflicts." PhD Diss., Wuhan University, May.

Dore, J. 2014. "An Agenda for Deliberative Water Governance Arenas in the Mekong." Water Policy 16 (2): 194-214. doi:10.2166/wp.2014.204.

Edkins, J. 1999. Post-Structuralism and International Relations: Bringing the Political Back In. London: Lynne Rienner.

Feng, Y., W. Wang, D. Suman, S. Yu, and D. He. 2019. "Water Cooperation Priorities in the Lancang-Mekong River Basin Based on Cooperative Events since the Mekong River Commission Establishment." Chinese Geographical Science 29 (1): 58-69. doi:10.1007/ s11769-019-1016-4.

Floyd, R. 2007. "Towards a Consequentialist Evaluation of Security: Bringing Together the Copenhagen School and the Welsh School of Security Studies." Review of International Studies 33 (2): 327-350. doi:10.1017/S026021050700753X.

Gleick, P. 1990. "Environment, Resources, and International Security and Politics." In Science and International Security: Responding to a Changing World, edited by E. Arnett, 501-523. Washington, D.C.: American Association for the Advancement of Science Press.

Gong, X. 2020. "Non-Traditional Security Cooperation between China and South-East Asia: Implications for Indo-Pacific Geopolitics." International Affairs 96 (1): 29-48. doi:10.1093/ia/ iiz225.

Granit, J., and J. Joyce. 2012. "Options for Cooperative Action in the Euphrates and Tigris Region." Paper 20. Stockholm: SIWI.

Groenfeldt, D., and J. Schmidt. 2013. "Ethics and Water Governance." Ecology and Society 18 (1): 14. doi:10.5751/ES-04629-180114.

Gupta, J., A. Akhmouch, W. Cosgrove, Z. Hurwitz, J. Maestu, and O. Ünver. 2013. "Policymakers' Reflections on Water Governance Issues." Ecology and Society 18 (1): 35. doi:10.5751/ES05086-180135.

He, D., C. Liu, Y. Feng, J. Hu, X. Ji and Y. Li. 2014. 'Protress and Perspective of International River Researches in China' [Zhongguo Guoji Heliu Yanjiu Jinzhan Yu Zhanwang]. Acta Geographica Sinica 69 (9): 1284-1294.

Ho, S., N. Qian, and Y. Yan. 2019. "The Role of Ideas in the China-India Water Dispute." The Chinese Journal of International Politics 12 (2): 263-294. 
Hoff, H. 2011. Understanding the Nexus. Background Paper for the Bonn Conference: The Water, Energy and Food Security Nexus. Sweden: Stockholm Environment Institute.

Holbraad, M., and M. Pedersen. 2012. "Revolutionary Securitization: An Anthropological Extension of Securitization Theory." International Theory 4 (2): 165-197. doi:10.1017/ S1752971912000061.

Homer-Dixon, T. 2010. Environment, Scarcity, and Violence. Princeton, USA: Princeton University Press.

Huber, A., and D. Joshi. 2015. "Hydropower, Anti-politics, and the Opening of New Political Spaces in the Eastern Himalayas." World Development 76: 13-25. doi:10.1016/j.worlddev.2015.06.006.

International Rivers. 2020. "Victory on the Upper Mekong: Thai Cabinet Terminates Rapids Blasting Project." International Rivers, February 6. https://www.internationalrivers.org/ news/blog-victory-on-the-upper-mekong-thai-cabinet-terminates-rapids-blasting-project/

Jia, S, A. Lv, Y. Han, Q. Long, W. Zhu, and H. Yan. 2014. Water Resources Security: Report of China. Beijing: Science Press.

Jiang, H., M. Qiang, P. Lin, Q. Wen, B. Xia, and N. An. 2017. "Framing the Brahmaputra River Hydropower Development: Different Concerns in Riparian and International Media Reporting." Water Policy 19 (3): 496-512. doi:10.2166/wp.2017.056.

Johnson, T. 2020. "Public Participation in China's EIA Process and the Regulation of Environmental Disputes." Environmental Impact Review 81: 106359. doi:10.1016/j. eiar.2019.106359.

Jutila, M. 2006. “Desecuritizing Minority Rights: Against Determinism.” Security Dialogue 37 (2): 167-185. doi:10.1177/0967010606066169.

Kattelus, M, M. Kummu, M. Keskinen, A. Salmivaara, and O. Varis. 2015. "China's Southbound Transboundary River Basins: A Case of Asymmetry." Water International 40: 113-138. doi:10.1080/02508060.2014.980029.

Kittihoun, A., and D. Staubli. 2018. "Water Diplomacy and Conflict Management in the Mekong: From Rivalries to Cooperation." Journal of Hydrology 567: 654-667. doi:10.1016/ j.jhydrol.2018.09.059.

Kondolf, G., Z. Rubin, and J. Minear. 2014. "Dams on the Mekong: Cumulative Sediment Starvation." Water Resources Research 50 (6): 5158-5169. doi:10.1002/2013WR014651.

Li, Z. 2013. "Water Resource Security Involved in China_India Territorial Disputes." South Asian Studies Quarterly 13 (4): 29-34.

Ligtvoet, W., A. Bouwman, J. Knoop, S. de Bruin, K. Nabielek, H. Huitzing, J. Janse, J. van Minne, D. Gernaat, P. van Puijenbroek, J. de Ruiter and H. Visser. 2018. The Geography of Future Water Challenges. The Hague: PBL Netherlands Environmental Assessment Agency. https:// tinyurl.com/y5dp7hc2

Lu, H. 2019. "Japan's Diplomacy and Indo-Pacific Vision: An Analysis from the Perspective of International Public Goods." Japanese Studies 6: 1-23.

Mehdudia, S. 2011. "We Trust China's Promise on Dam: Manmohan." The Hindu, August 5. Accessed 18 December 2020. http://www.thehindu.com/news/national/we-trust-chinaspromise-on-dam-manmohan/article2322266.ece

Mehtonen, K., M. Keskinen, and V. Olli. 2008. "The Mekong: IWRM and Institutions." In Management of Transboundary Rivers and Lakes, edited by N. Pachova, M. Nakayama, and L. Jansky, 207-226. Berlin: United Nations University Press.

Mekong River Commission. 2016. "China Discuss Joint Study." News release, May 6. Accessed 18 December 2020. http://www.mrcmekong.org/news-and-events/news/chinasemergency-water-supply-increased-mekongs-water-level-says-an-mrc-china-joint-study/

Mekong River Commission. 2020a. Understanding the Mekong River's Hydrological Conditions: A Brief Commentary Note on the "Monitoring the Quantity of Water Flowing through the Upper Mekong Basin under Natural (Unimpeded) Conditions.". Vientiane: MRC Secretariat. 
Mekong River Commission. 2020b. "MRC Secretariat Welcomes China's Pledge to Share Mekong Data but Suggests Harnessing Existing Platform." August 25. Accessed 18 December 2020. https://www.mrcmekong.org/news-and-events/news/pr-mrcs-welcomeschina-pledge/

Messay, M. 2020. "The Need for Clarity: Securitization of Water Vs. Water Security." The Reporter, May 9. https://www.thereporterethiopia.com/article/need-clarity-securitizationwater-vs-water-security

Ministry of External Affairs. 2014. "Joint Statement between the Republic of India and the People's Republic of China on Building a Closer Developmental Partnership." September 19. Accessed 18 December 2020. http://www.mea.gov.in/bilateral-documents.htm?dtl/ 24022/Joint+Statement+between+the+Republic+of+India+and+the+Peoples+Republic +of+China+on+Building+a+Closer+Developmental+Partnership Accessed 30 July 2019.

Ministry of Water Resources. 2017. "Water Resource Cooperation Is to Be Promoted as Flagship for LMCM." News lease, December 21. Accessed 18 December 2020. http://gjkj. mwr.gov.cn/jdxw/201712/t20171221_1018130.html

Ministry of Water Resources, River Development and Ganga Rejuvenation. 2014. "India-China Co-Operation." September 19, Accessed 20 November 2015. http://wrmin.nic.in/forms/list. aspx?lid=349

Muller, M. 2015. "Water and Regional Integration: The Role of Water as a Driver of Regional Economic Integration in Southern Africa." June. WRC Report No 2252/1/14/. Pretoria: Water Research Commission.

Oels, A. 2012. "From 'Securitization' of Climate Change to 'Climatization' of the Security Field: Comparing Three Theoretical Perspectives." In Climate Change, Human Security and Violent Conflict. Hexagon Series on Human and Environmental Security and Peace, edited by J. Scheffran, M. Brzoska, H. Brauch, P. Link, and J. Schilling, 185-205. Berlin, Heidelberg: Springer.

Ovodenko, A. 2016. "Regional Water Cooperation: Creating Incentives for Integrated Management." Journal of Conflict Resolution 60: 1-28. doi:10.1177/0022002714553109.

Peoples, C., and N. Vaughan-Williams. 2010. Critical Security Studies: An Introduction. London and New York: Routledge.

Petri, P., and M. Plummer. 2020. "RCEP: A New Trade Agreement that Will Shape Global Economics and Politics." November 16. Accessed 18 December 2020. https://www.brook ings.edu/blog/order-from-chaos/2020/11/16/rcep-a-new-trade-agreement-that-will-shape -global-economics-and-politics/

PTI. 2019. "China Begins Sharing Hydrological Data for Bramhaputra for Monsoon Season." May 20. Accessed 18 December 2020. http://timesofindia.indiatimes.com/articleshow/ 69416077.cms?utm_source=contentofinterest\&utm_medium=text\&utm_campaign= cppst

Rai, S., N. Sharma, and A. Lohani. 2019. "Novel Approach for Issues Identification in Transboundary Water Management Using Fuzzy C-means Clustering." Applied Water Sciences 9 (11). doi:10.1007/s13201-018-0889-1.

Rigi, H., and J. Warner. 2020. "Two-Level Games on the Trans-boundary River Indus: Obstacles to Cooperation." Water Policy 22 (6): 972-990. doi:10.2166/wp.2020.090.

Roberts, T. 2004. "Fluvicide: An Independent Environmental Assessment of Nam Theun 2 Hydropower Project in Laos, with Particular Reference to Aquatic Biology and Fishes." Accessed 18 December 2020. https://portals.iucn.org/library/node/27540

Ruan, Z. 2014. "'Zhongguo Xuyao Goujian Zengyang De Zhoubian." [What Kind of Neighborhood Does China Need to Build]." Guoji Wenti Yanjiu 2: 11-26. 
Salman, M. 2007. "The United Nations Watercourses Convention Ten Years Later: Why Has Its Entry into Force Proven Difficult?" Water International 32 (1): 1-15. doi:10.1080/ 02508060708691962.

Shan, P. 2016. "Legislation on the Acquisition of Water Rights and Their Priorities." Tsinghua University Law Journal 10 (1): 142-159.

Shapiro, J. 2012. China's Environmental Challenges. Cambridge and Malden MA: Polity Press. Sharma, P. 2020. "Water Wars: How China Weaponizes Rivers." June 21. Accessed 18 December 2020. https://www.wionews.com/world/water-wars-how-china-weaponisesrivers-314975

Shen, W., and L. Xie. 2018. "Can China Lead in Multilateral Environmental Negotiations? International Politics, Self-Depiction, and China's Contribution in Climate Change and Mekong Governance." Eurasian Geography and Economics 59 (5-6): 708-732. doi:10.1080/15387216.2019.1586557.

Shermer, S. 2005. "The Drinking Water Security and Safety Amendments of 2002: Is America's Drinking Water Infrastructure Safer Four Years Later?" UCLA Journal of Environmental Law \& Policy 24: 355-457.

Shi, Y. 2013. "'Zhongguo Zhoubian Xingwei Zhong Cengyoude "Shengli Zhuyi": Dongneng He Juece Fuzaxing." [The Triumphalism in China's Neighborhood Behavior]." Xiandai Guoji Guanxi 10: 3-5.

Simpson, A., and M. Smits. 2018. "Transitions to Energy and Climate Security in Southeast Asia? Civil Society Encounters with Illiberalism in Thailand and Myanmar." Society \& Natural Resources 31 (5): 580-598. doi:10.1080/08941920.2017.1413720.

Starr, J. 1991. "Water Wars." Foreign Policy 82 (Spring): 17-36. doi:10.2307/1148639.

Trombetta, M. 2008. "Environmental Security and Climate Change: Analysing the Discourse." Cambridge Review of International Affairs 4 (21): 585-602. doi:10.1080/ 09557570802452920.

UNEP and the Asian Institute of Technology (AIT). 2009. "Freshwater Under Threat." Accessed 10 December 2020. http://staging.unep.org/pdf/SEA_Water_report.pdf

United Nations. 2007. "Security Council Debate on Impact of Climate Change." United Nations Security Council. http://www.un.org/press/en/2007/sc9000.doc.htm

United Nations. 2013. "Water Security and the Global Water Agenda." Accessed 10 December 2020. https://collections.unu.edu/view/UNU:2651

United Nations. 2014. "Water and Energy Sustainability." United Nations. Accessed 18 December 2020. http://www.un.org/waterforlifedecade/pdf/01_2014_sustainability_eng. pdf

United Nations. 2016. UN-Water Annual Report 2016. https://www.unwater.org/publications/ un-water-annual-report-2016/

Urban, F., G. Siciliano, and J. Nordensvard. 2018. "China's Dam-Builders: Their Role in Transboundary River Management in South-East Asia." International Journal of Water Resources Development 34 (5): 1-25. doi:10.1080/07900627.2017.1329138.

Urban, F., G. Siciliano, K. Sour, P. Lonn, M. Tan, and G. Mang. 2015. "South-South Technology Transfer of Low-Carbon Innovation: Large Chinese Hydropower Dams in Cambodia." Sustainable Development 23: 232-244. doi:10.1002/sd.1590.

Varis, O., M. Kummu, C. Lehr, and D. Shen. 2014. "China's Stressed Waters: Societal and Environmental Vulnerability in China's Internal and Transboundary River Systems." Applied Geography 53: 105-116. doi:10.1016/j.apgeog.2014.05.012.

Vuori, J. 2008. "Illocutionary Logic and Strands of Securitisation: Applying the Theory of Securitisation to the Study of Non-Democratic Political Orders." European Journal of International Relations 14 (1): 65-99. doi:10.1177/1354066107087767. 
Vuori, J. 2018. "Let's Just Say We'd like to Avoid Any Great Power Entanglements: Desecuritization in Post-Mao Chinese Foreign Policy Towards Major Powers." Global Discourse 8 (1): 118-136. doi:10.1080/23269995.2017.1408279.

Waever, O. 2000. "The EU as a Security Actor: Reflections from a Pessimistic Constructivist on Post Sovereign Security Orders." In International Relations Theory and the Politics of European Integration, edited by M. Kelstrup and M. Williams, 250-294. London: Routledge.

Warner, J. 2004. "Plugging the Gap, Working with Burzan: The Llisu Dam as a Security Issue." Occasional Paper, no 67, SOAS.

Warner, J. 2016. "Of River Linkage and Issue Linkage: Transboundary Conflict and Cooperation on the River Meuse." Globalizations 13 (6): 741-766. doi:10.1080/14747731.2015.1136786.

Warner, J., P. Wester, and J. Hoogesteger. 2014. "Struggling with Scales: Revisiting the Boundaries of River Basin Management." Wiley Interdisciplinary Reviews: Water 1 (5): 469-481. doi:10.1002/wat2.1035.

Wei, T. 2011. "Development of China's Water Culture Concepts Viewed from Water." Journal of China University of Mining and Technology (Social Science), 6 (25): 130-134.

Wilkinson, C. 2007. "The Copenhagen School on Tour in Kyrgyzstan: Is Securitization Theory Useable outside Europe?" Security Dialogue 38: 5-26. doi:10.1177/0967010607075964.

Williams, G., and E. Mawdsley. 2006. "Postcolonial Environmental Justice: Government and Governance in India." Geoforum 37 (5): 660-670. doi:10.1016/j.geoforum.2005.08.003.

Wittfogel, K. 1957. Oriental Despotism. New Haven: Yale University Press.

Wolf, A. 1999. "'Water Wars" and Water Reality: Conflict and Cooperation along International Waterways." In Environmental Change, Adaptation, and Security, edited by S. Lonergan, 251-265. Dordrecht: Springer.

Wolf, A., A. Kramer, A. Carius, and G. Dabelko. 2005. "Managing Water Conflict and Cooperation." In State of the World: Redefining Global Security, edited by L. Starke, 80-95. Washington, D.C.: Worldwatch Institute.

World Bank. 2019. "Watershed: A New Era of Water Governance in China - Thematic Report." Washington, DC: World Bank. Accessed 21 December 2020. https://openknowledge.world bank.org/handle/10986/33009

Xie, J. 2009. "Addressing China's Water Scarcity: Recommendations for Selected Water Resource Management Issues." World Bank. Accessed 18 December 2020. https://open knowledge.worldbank.org/handle/10986/2585

Xie, L. 2015. "Political Participation and Environmental Movements in China." In International Handbook of Political Ecology, edited by R. Bryant, 246-259. Cheltenham: Edward Edgar Publishing.

Xie, L., and L. Xu. 2021. "Environmental Public Interest Litigation in China: A Critical Examination." Transnational Environmental Law. doi:10.1017/S2047102520000448.

Xie, L., and S. Jia. 2017. "Diplomatic Water Cooperation: The Case of Sino-India Dispute over Brahmaputra." International Environmental Agreement, Politics, Law and Economics 17: 677-694. doi:10.1007/s10784-016-9339-4.

Xie, L., and S. Jia. 2018. China's International Transboundary Rivers: Politics, Security and Diplomacy of Shared Water Resources. London and New York: Routledge.

Xie, L., Y. Zhang, and J. Panda. 2017. "Mismatched Diplomacy: China-India Water Relations over the Ganges-Brahmaputra-Meghna River Basin." Journal of Contemporary China 27 (109): 32-46. doi:10.1080/10670564.2017.1363014.

Xinhua News. 2011. "China Increases Technological Cooperation with the Mekong River Riparian States on Water Management." November 25. Accessed 18 December 2020. http://www.chinanews.com/gn/2011/11-25/3487521.shtml

Yan, J. 2017. "Water Security in China's Transboundary Rivers." Doctoral thesis, Chinese Academy of Sciences. 
Yu, X. 2006. Feichuantong Anquan Yanjiu [Non-traditional Security Study]. Zhejiang: Zhejiang People's Press.

Yu, X., and Z. Zhou. 2014. "Identification, Assessment and Solution for Non-Traditional Security Threats of Sino-Indian Transboundary Rivers." World Economics and Politics 12: $52-70$.

Zeitoun, N., and M. Mirumachi. 2008. "Transboundary Water Interaction I: Reconsidering Conflict and Cooperation." International Environmental Agreements 8: 297-316. doi:10.1007/s10784008-9083-5.

Zeng, J., Y. Xiao and S. Breslin. 2015. 'Securing China's Core Interests: the State of the Debate in China'. International Affairs 2 (91): 245-266.

Zha, D. 2014. "A Political Ecology of Hydropower Development in China." In Hydropower Development in the Mekong Region: Political, Socio-economic and Environmental Perspectives, edited by M. Matthews and K. Geheb, 32-53. London and New York: Routledge.

Zhang, J., and J. Bai. 2004. "Property Right Study in Water Resource Allocation." Journal of Xi'an University of Finance and Economics 17 (6): 74-77. [in Chinese]. 